\title{
Enhanced recovery after cardiac surgery
}

\author{
Tadeusz Kołodziej, Tomasz Maciejewski, Konrad Mendrala, Tomasz Darocha, Andrzej Węglarzy, \\ Barbara Budziarz, Kazimierz Kiermasz, Ewa M. Kucewicz-Czech
}

Department of Cardiac Anaesthesiology and Intensive Therapy, Medical University of Silesia, Katowice, Poland

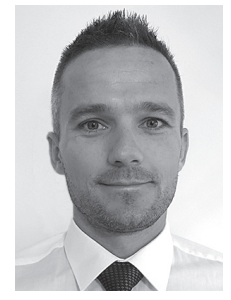

Kardiochirurgia i Torakochirurgia Polska 2019; 16 (1): 32-36

\begin{abstract}
The concept of early recovery after surgery (ERAS) consists of bundle interventions during the pre-, intra- and postoperative periods and team work. The ERAS, which is a multimodal strategy, enables one to limit the neurohumoral response to the surgery, maintain homeostasis, reduce the risk of complications, shorten the hospital stay, accelerate the return to everyday functioning, improve the patient's satisfaction, achieve a satisfactory quality of life and finally reduce the treatment costs and eliminate any redundant and ineffective practices. Almost every patient can be classified for the ERAS strategy except for patients undergoing urgent and emergency surgery. The necessity to give up ERAS can result from poor organisation and management. Moreover, the procedure itself can be the cause of the lack of adherence to the planned standard. It is necessary to use protocols and checklists. While fulfilling this doctrine, the anaesthesiologist becomes a perioperative specialist.
\end{abstract}

Key words: early recovery after surgery, cardiac surgery, postoperative complications.

\section{Streszczenie}

Koncepcja ERAS określana jest w polskiej nomenklaturze jako protokół kompleksowej opieki okołooperacyjnej dla poprawy wyników leczenia. Realizacja koncepcji ERAS, która jest strategią multimodalną, prowadzi do ograniczenia odpowiedzi neurohormonalnej na uraz, zachowania homeostazy, ograniczenia ryzyka wystąpienia powikłań, skrócenia czasu pobytu w szpitalu, przyspieszenia powrotu do normalnego codziennego funkcjonowania, poprawy satysfakcji pacjenta, osiągnięcia zadowalającej jakości życia i ostatecznie redukcji kosztów leczenia, unikania niegospodarności i marnotrawstwa. Realizowana jest kompleksowo w okresie przed-, śród- i pooperacyjnym. Istotnym dylematem, który należy rozstrzygnąć, wdrażając strategię ERAS, jest selekcja pacjentów. Można zakwalifikować do niej prawie każdego pacjenta, z wyjątkiem chorych operowanych w trybie pilnym. Przyczyną niepowodzeń w realizacji strategii ERAS są czynniki związane z pacjentem, procedurą i zarządzaniem. Niedopełnienie protokołów przygotowania przedoperacyjnego, nieprzestrzeganie zasad znieczulenia, odzwyczajania od wentylacji mechanicznej płuc, nieprzestrzeganie protokołu sedacji czy schematu leczenia bólu to zdarzenia niepożądane o charakterze organizacyjnym. Konieczne jest stosowanie standardów, protokołów i list kontrolnych. W realizacji tej procedury anestezjolog staje się specjalistą okołooperacyjnym.

Słowa kluczowe: protokół kompleksowej opieki okołooperacyjnej dla poprawy wyników leczenia, kardiochirurgia, powikłania pooperacyjne.

concept of early recovery after surgery (ERAS), borrowed from sportsmen and introduced to medicine by Professor Henrik Kehlet, Kenneth Fearon and Olle Ljungqvist, can be used for this purpose. They worked out the standard of short hospitalisation with maximum limitation of complications for surgical patients [1]. In Polish literature, ERAS is defined as the protocol of comprehensive perioperative care designed to improve treatment outcomes.

In the 1990s, attempts were made to modify perioperative management in patients undergoing cardiac surgery,

Address for correspondence: Prof. Ewa M. Kucewicz-Czech MD, PhD, Department of Cardiac Anaesthesiology and Intensive Therapy, Medical University of Silesia, 15 Medyków St, 40-752 Katowice, Poland, phone: +48 604451 880, e-mail: j.ciesla@sccs.pl

Received: 18.12.2018, accepted: 15.01.2019. 
defined as fast track [2]. The time of mechanical lung ventilation was shortened, which enabled the stays in post-anaesthesia care units or intensive care units to be reduced. The experience gained then proved that the innovative management was safe.

Surgery is an extreme injury to the organism, especially in elderly patients. A surgical insult increases oxygen requirements of the myocardium, which is associated with the risk of ischaemia. Vasoconstriction in visceral vessels can cause dysfunction of abdominal organs due to ischaemia. The depletion of energy stores (excitation, shivers) weakens both the peripheral and respiratory muscles. Hyperglycaemia favours impaired healing and leads to surgical site infections. Finally, hypercoagulation as well as water and sodium retention that accompany the surgical procedure can aggravate organ dysfunctions.

The ERAS, which is a multimodal strategy, enables one to limit the neurohumoral response to the insult, maintain homeostasis, reduce the risk of complications, shorten the hospital stay, accelerate the return to everyday functioning, improve the patient's satisfaction, achieve the satisfactory quality of life and finally reduce the treatment costs and eliminate any redundant and ineffective practices. The ERAS is divided into three stages: pre-, intra- and postoperative [3].

In 2015, a list of priority studies in anaesthesia and perioperative medicine was published [4]. Among the ten most important problems to be solved based on clinical studies was the issue of scientific evidence confirming the improvement in short- and long-term outcomes after the implementation of ERAS.

In 2016, the first pilot study was published, which analysed enhanced recovery after cardiac surgery (ERACS), i.e. the effects of the introduction of ERAS elements in patients undergoing cardiac surgical procedures [5]. The authors prove that the use of the ERACS strategy is feasible and has the potential to reduce the early postoperative complications.

\section{The preoperative period}

The preoperative management is focused on the provision of detailed information and counselling as well as lifestyle interventions. The aim of prehabilitation is to improve the physical and mental capabilities of patients using exercises, diets, psychotherapy, and cessation of alcohol and tobacco smoking. Such interventions are introduced in advance before the surgical treatment. Adherence to the prehabilitation rules can limit the risk of bleeding, surgical wound infections, cardiac and respiratory dysfunctions [6]. Another problem of the preoperative period is anaemia, which is diagnosed in $75 \%$ of cardiac surgery patients and is a risk factor of complications and mortality [7]. Evidencebased medicine clearly discourages qualification of patients with anaemia for elective surgery [8].

Premedication with benzodiazepines that increase the risk of delirium and other long-acting drugs should be avoided. A good choice is drugs reducing the opioid requirements in the postoperative period. Premedication with pre- gabalin administered in a dose of $75 \mathrm{mg}$ limits morphine requirements and reduces the incidence of chronic pain. The effect is visible after a single dose of the drug. The side effects, such as somnolence and dizziness, are less common compared to gabapentin. The mechanism of action of gabapentinoids involves the modulation of ion flow in the calcium channels, limiting the central susceptibility by reducing the release of transmitters [9]. Another drug that can limit cognitive and sleep disorders is melatonin, which can be used for premedication [10].

The up-to-date management in preparation for surgery is the administration of fluids containing simple and complex carbohydrates (maltodextrose) until the evening preceding the day of surgery and during the surgery day up to 2 hours before the entry to the operating room. The use of fluids with carbohydrates prevents thirst and hunger, reduces the level of anxiety, prevents hypovolaemia, insulin resistance and protein catabolism in the postoperative period, and improves muscle functions, including the respiratory muscles [11].

\section{The intraoperative period}

During surgery, normothermia should be maintained. Hypothermia prolongs drug metabolism, causes coagulopathy, induces shivers increasing the oxygen requirements, favours cognitive disturbances, and increases the incidence of surgical site infections. The fundamental objective is to maintain and not to restore normothermia during anaesthesia.

Pharmacotherapy used for anaesthesia is essential. Inhalation anaesthetics should be applied (sevoflurane, desflurane) in a dose of 0.8-1.0 minimal alveolar concentration (MAC) and/or propofol in a dose of $3 \mathrm{mg} / \mathrm{kg} / \mathrm{h}$. The recommended opioids are sufentanil (cumulative dose 5-10 $\mu \mathrm{g} / \mathrm{kg}$ ), fentanyl (cumulative dose 5-15 $\mu \mathrm{g} / \mathrm{kg}$ ) and remifentanil (0.2-0.75 $\mu \mathrm{g} / \mathrm{kg}$ in, the dose should be tailored to the intensity of stimuli from the operative field). As far as muscle relaxants are concerned, rocuronium (0.6-1.0 mg/kg - intubation dose; $0.075-0.15$ - maintenance dose) or cisatracurium $(0.1-0.4 \mathrm{mg} / \mathrm{kg}$ - intubation dose; 0.03-0.15 - maintenance dose) should be chosen [12].

Postoperative pain should be prevented already in the intraoperative period. Intravenous non-opioid analgesics should be administered before skin incision. Such a pre-emptive management option is intravenous metamizole in a dose of $1 \mathrm{~g}$. Moreover, to limit the postoperative dose of opioids, intravenous ketamine in a dose of $30 \mathrm{mg}$ can be administered after the induction of anaesthesia. Ketamine is an N-methylD-aspartate (NMDA); its action is not limited to the reduction in opioid requirements. It also shows antiemetic effects and prevents chronic pain, which is a relevant problem in the remote period. The reports regarding the efficacy of ketamine, its dose and time of administration are not explicit [13]. The lack of side effects when administered for general anaesthesia and promising results of some studies speak in favour of its use. The infiltration of the surgical wound with $60 \mathrm{ml}$ of levobupivacaine $(30 \mathrm{ml}$ on both sides of sternotomy and 
$15 \mathrm{ml}$ around the drains) reduces the requirements for opioids and sedation in the postoperative period [14]. The study did not demonstrate any side effects of infiltration; nevertheless, the population size was small; therefore, the results should be validated in larger populations.

A serious and common postoperative complication is respiratory failure. In order to prevent it, intraoperative protective lung ventilation should be implemented. It is recommended to use low concentrations of oxygen in the respiratory mixture. An exception is the moment of completion of extracorporeal circulation when the use of $100 \%$ oxygen is admissible. The tidal volume should be calculated based on the ideal body weight (height in $\mathrm{cm}$ minus 100), administering $8 \mathrm{ml}$ of respiratory mixture per $\mathrm{kg}$ of the calculated body weight. During anaesthesia positive end-expiratory pressure (PEEP) should be maintained at the level of $5 \mathrm{~cm}$ $\mathrm{H}_{2} \mathrm{O}$. Similar rules of mechanical lung ventilation should be observed in the early postoperative period. In patients with hypoxaemia (requiring the oxygen concentration in the respiratory mixture $>50 \%$ ), the parameters of ventilation should be changed - tidal volume of $6 \mathrm{ml} / \mathrm{kg}$ of ideal body weight and PEEP of 8-13 $\mathrm{cm} \mathrm{H}_{2} \mathrm{O}$. After filling the vascular bed, the lung recruitment manoeuvre should be applied, and another one after 4 hours. The recruitment manoeuvre can be carried out using any of the approved methods; an important element of management is not to exceed the driving pressure (the difference between plateau pressure and PEEP) by $10 \mathrm{~cm} \mathrm{H} \mathrm{H}_{2} \mathrm{O}$. The management option described should be the method of choice as the most common cause of postoperative hypoxaemia is atelectasis. The first reaction to hypoxaemia cannot be an increase in the oxygen concentration in the respiratory mixture. In cases of hypoxaemia, hypercapnia, and impaired mechanical lung ventilation when atypical ventilator settings are required, lung ultrasound should be performed to diagnose the cause of potential respiratory failure [15].

Recently, goal-directed therapy has gained much interest. Its efficacy in some areas of intensive care has not been confirmed [16]. In the perioperative care of high-risk patients, goal-directed therapy enables one to limit the number of complications, and shorten the time of hospitalisation and intensive care unit (ICU) stay [17-19]. To cover fluid requirements during anaesthesia, intravenous administration of $1-3 \mathrm{ml} / \mathrm{kg} \mathrm{cc} / \mathrm{h}$ of balanced crystalline fluids is needed. This protocol can be introduced when we are sure that the patient entering the operating room is normovolaemic.

Additional fluid transfusions should be confined to patients who react with increased cardiac output to increased intravascular volume. In special cases, monitoring of cardiac output is recommended (complex procedures, severe cardiac dysfunction). Echocardiography and Swan-Ganz catheters are used for this purpose. Goal-directed therapy enables to estimate the optimal volume of fluids [20, 21]. The fluids of choice are balanced solutions of electrolytes. The transfusion of $0.9 \% \mathrm{NaCl}$ results in hyperchloraemic acidosis, which causes renal artery stenosis and increases the number of complications and mortality rates. Perioperative monitoring of chlorine concentrations is recommended. When synthetic colloids are administered, their volume should be limited to $20 \mathrm{ml} / \mathrm{kg} \mathrm{cc} /$ day. Indications for transfusions of blood and its preparations are anaemia and haemorrhage. At present, neither restrictive nor liberal fluid therapy is considered. The aim is to maintain a zero balance, which means fluid supplementation. Noteworthy, the hourly urine volume during surgery does not reflect the vascular bed filling; hourly diuresis below $0.5 \mathrm{ml} / \mathrm{h}$ is not a risk factor of kidney failure. Intraoperative oliguria results from the release of stress and antidiuretic hormones. Clearance of fluids during anaesthesia is only a small fraction of the value observed in the conscious state. During anaesthesia permissive oliguria can be tolerated, which is not an indication for fluid administration if it is an isolated symptom. Anuria is an alarming symptom and requires quick diagnosis.

A surgical insult induces hyperglycaemia and hypercoagulation. Several minutes after skin incision, the hypothalamus stimulates the release of pituitary hormones and in consequence of cortisol, which leads to gluconeogenesis, protein catabolism and loss of muscle mass. The activation of the sympathetic system generates the release of endogenous amines and intensifies hyperglycaemia. Improper control of glycaemia increases the risk of infection and incidence of cardiac events or even deaths. The blood concentration of glucose should be maintained within the limits of $140-180 \mathrm{mg} / \mathrm{dl}$. More restrictive control is indicated in some selected patients provided that hypoglycaemic incidents are fully prevented [22]. Cytokines and acute phase proteins circulating in blood create hypercoagulation but also stimulate fibrinolysis.

\section{The postoperative period}

In the postoperative period, oral intake of liquids should be initiated as quickly as possible. The only contraindications are nausea and vomiting. Intravenous fluid administration after surgery shows no benefits. To cover fluid requirements after surgery, the patient should receive 1.5-1.7 I of fluids per day. In the majority of cases, ad libitum intake is possible, which increases the patient's satisfaction with treatment. A relevant aspect of monitoring is fluid balance. The daily balance around zero decreases the risk of complications and shortens the hospital stay. The balance can be controlled during the first postoperative days by weighing patients. The weight and balance are strictly correlated in the first four postoperative days. Moreover, early oral feeding is essential. It should be started 24 hours after surgery. This protocol of management reduces insulin resistance and nitrogen excretion, limits the muscle mass loss, improves wound healing, and decreases the risk of lung and surgical site infections.

Postoperative nausea and vomiting (PONV) should be prevented according to the Apfel score. The use of propofol for anaesthesia reduces the incidence of PONV. Similar effects are produced by short-term fasting, preoperative administration of fluids with carbohydrates and perioperative 
normovolaemia. In patients with nausea and/or vomiting, at least two drugs should be used - dexamethasone and ondansetron. The presence of a gastric tube increases the incidence of vomiting, atelectasis and pneumonia. There are no rational reasons for routine tube leaving after surgery. The tube should be left only in cases of prolonged postoperative ileus [23]. Paralytic ileus in the postoperative period results from the limited release of intestinal hormones, the impaired function of the central or autonomic nervous system and the release of inflammatory response transmitters. Oral intake of magnesium, administration of laxatives and osmotic drugs (lactulose), chewing gum with sorbitol/hexitol, and solid foods improve peristalsis.

Pain management is essential. The therapy should be adjusted to the procedure performed. Multimodal analgesia is the treatment of choice. After cardiac procedures (sternotomy, thoracotomy) the maximum pain intensity is observed on the first two postoperative days. Female and male patients below the age of 60 years have stronger pain sensations. Each department or unit should have the standard of pain management. The concept of early Comfort using Analgesia, minimal Sedation, maximal Humane care (eCASH) is the essence of optimal perioperative care. It includes the $3 \mathrm{C}$ rule (Comfortable, Cooperative, Calm). The first step of this brilliant strategy is analgesia. Sedation should be targeted and the target is quick mobilisation. The prerequisite of success is the promotion of proper cycles of sleep and staying awake, good atmosphere in the unit and family involvement. A dramatic postoperative complication increasing the risk of death is delirium $[23,24]$. The predisposing factors are older age, history of cognitive disturbances, generalised atherosclerosis, and anaemia. The triggering factors are acute destabilisation of the clinical condition (e.g. low cardiac output syndrome, hypotonia or acute kidney failure), use of opioids plus persistent pain, use of benzodiazepines and others. In high-risk patients, a low dose of haloperidol for prevention can be administered. Similar effects can be achieved with a low dose of atypical neuroleptics - risperidone (1 mg after), olanzapine or dexmedetomidine sedation. Quetiapine reduces the duration of delirium. The outcomes of such preventive interventions are not explicit [25].

Another problem associated with the postoperative period is atrial fibrillation, which affects about 30\% of patients [26]. Atrial fibrillation is a risk factor of central nervous system (CNS) stroke, acute kidney failure requiring renal replacement therapy, prolonged hospital stay and mortality. The patients should receive $\beta$-blockers in the morning of the surgery day and immediately after the procedure. However, competitive action towards catecholamines in the early postoperative period should be considered; therefore, the time of administration of $\beta$-blockers should be individualised [27]. Moreover, drug doses should also be individually tailored.

The ERAS introduced the term of early goal-directed mobilisation [28]. Early mobilisation is a prerequisite of success of this state-of-the-art strategy. It involves physi- cal exercises and walking already during the surgery day. Thanks to such physiotherapy, the hospital stay has been shortened and the self-reliance scores during the 6 posthospitalisation months have improved. In patients undergoing cardiac surgical procedures, this management should be introduced during the first postoperative day. The main idea that should be considered by all individuals involved in surgery is the individualisation of management. There is no such measure that matches all individuals.

\section{Implementation of the ERACS strategy}

The first dilemma when implementing the ERACS strategy is the selection of patients. Almost every patient can be prepared, except for patients undergoing urgent and emergency surgery. However, it should be taken into account that the incidence of failures in the implementation of the entire protocol ranges between 3.3\% and 63\%. The causes of failures include patient-, procedure- and managementrelated factors (although to a lesser degree) [12]. The patient-dependent factors include older age, female gender, left ventricular ejection fraction > 30\%, fresh myocardial infarct, severe pulmonary hypertension, low cardiac output syndrome/cardiogenic shock immediately after surgery, kidney and respiratory failure, disorientation, and cognitive disorders. Moreover, the procedure itself can be the cause of the lack of adherence to the planned standard. This is most commonly observed in cases of re-surgery or complex urgent procedures. The procedure can also be additionally complicated by postoperative bleeding, tamponade, necessary surgical revision and unanticipated incidents. Moreover, the necessity to give up ERACS can result from poor organisation and management. Failure to observe the protocols of preoperative preparation and rules regarding the anaesthesia, weaning from a ventilator, and the protocol of sedation or pain management strategy are adverse events associated with organisation [28].

The effects of ERACS implementation should be confirmed in studies. The introduction is extremely slow as the habits are difficult to change. The ERACS is a challenge for the traditional surgical doctrine and it has its opponents. It requires team work. The prepared patient should be managed by the prepared team. It is necessary to use standards, protocols and checklists. While fulfilling this doctrine, the anaesthesiologist becomes a perioperative specialist.

The original ERAS, best analysed in colorectal surgery, contains 22 perioperative interventions. The implementation of ERAS in cardiac surgery patients should optimally be based on the Deming cycle, the scheme illustrating the basic rule of continuous improvement. The cycle consists of 4 stages - Plan-Do-Check-Act. The elements of ERAS should be chosen and verified in a pilot study, and the results should be analysed and implemented to the standard of perioperative care.

\section{Disclosure}

The authors report no conflict of interest. 


\section{References}

1. Vymazal T. Fast-track is more than physiological anaesthesia. Heart Lung Vessels 2014; 6: 77-78.

2. Wong WT, Lai VKW, Chee YE, Lee A. Fast-track cardiac care for adult cardiac surgical patients. Cochrane Database Syst Rev 2016; 9: CD003587.

3. Gustafsson UO, Scot MJ, Schwenk W, Demartines N, Roulin D, Franci N, McNaught CE, MacFie J, Liberman AS, Soop M, Hill A, Kennedy RH, Lobo DN, Fearon K, Ljungqvist O. Guidelines for perioperative care in elective colonic surgery: Enhanced Recovery After Surgery (ERAS) Society recommendations. Clin Nutr 2012; 31: 783-800.

4. Boney O, Bell M, Bell N, Conquest A, Cumbers m, Drake S, Galsworthy M, Gath J, Grocott MPW, Harris M, Howell S, Ingold A, Nathanson AH, Pinkney T, Metcalf L. Identifying research priorities in anaesthesia and perioperative care: final report of the joint National Institute of Academic Anaesthesia/ James Lind Alliance Research Priority Setting Partnership. BMJ Open 2015; 5: e010006.

5. Fleming IO, Garrat C, Guha R, Desai J, Chaubey S, Wang, Leonard S, Kunst G. Aggregation of marginal gains in cardiac surgery: feasibility of a perioperative care bundle for enhanced recovery in cardiac surgical patients. J Cardiothorac Vasc Anesthesia 2016; 30: 665-670.

6. Perry R, Scott LJ, Richards A, Haase AM, Savovic J, Ness AR, Atkinson Ch, Harris J, Culliford L, Shah S, Pufulete M. Pre-admission interventions to improve outcome after elective surgery - protocol for systemic review. Syst Rev 2016; 5: 88 .

7. Muńoz M, Gómez-Ramírez S, Kozek-Langeneker S, Shander L, Richards T, Pavía J, Kehlet H, Acheson AG, Evans C, Raobaikady R, Javidroozi M, Auerbach $M$. 'Fit to fly': overcoming barriers to preoperative haemoglobin optimization in surgical patients. Br J Anaesth 2015; 115: 15-24.

8. Spahn DR, Zacharowski K. Non-treatment of preoperative anaemia is substandard clinical practice. Br J Anaesth 2015; 115: 1-3.

9. Bouzia A, Tassoudis V, Karanikolas M, Vretzakis G, Petsiti A, Tsilimingas N, Arnaoutoglou E. Pregabalin effect on acute and chronic pain after cardiac surgery. Anesth Research Practice 2017; 2017: 2753962.

10. Artemiou P, Bily B, Bilecova-Rabajdova M, Sabol F, Torok P, Kolarcik P, Kolesa A. Melatonin treatment in the prevention of postoperative delirium in cardiac surgery patients. Kardiochir Torakochirur Pol 2015; 12: 126-133.

11. Melnyk M, Casey RG, Black P, Koupparis AJ. Enhanced recovery after surgery (ERAS) protocols: time to change practice? Can Urol Assoc J 2011; 5: 342-348.

12. Probst S, Ender J. Enhanced recovery from heart surgery. In: Oxford Textbook of Cardiothoracic Anaesthesia. Alston RP, Myles PS, Ranucci M (eds). Oxford University Press 2015. Chapter 27.

13. Bell RF, Dahl JB, Moore RA, Kaiso E. Peri-operative ketamine for acute postoperative pain: a quantitative and qualitative systemic review (Cochrane review). Acta Anaesthesiol Scand 2005; 49: 1405-1428.

14. Kocabas S, Yedicocuklu D, Yuksel E, Uysallar E, Askar F. Infiltration of the sternotomy wound and the mediastinal tube sites with $0.25 \%$ levobupivacaine as adjunctive treatment for postoperative pain after cardiac surgery. Eur J Anaesthesiol 2008; 25: 842-849.

15. Miskovic A, Lumb AB. Postoperative pulmonary complications. Br J Anaesth 2017; 118: 317-334.
16. Yealy DM, Kellum JA, Huang DT, Barnato AE, Weissfeld LA, Pike F, Terndrup T, Wang HE, Hou PC, LoVecchio F, Filbin MR, Shapiro NI, Angus DC; The ProCESS Investigators. The randomized trial of protocol-based care for early septic shock. N Engl J Med 2014; 370: 1683-1693.

17. Osawa EA, Rhodes A, Landoni G, Galas F, Fukushima JT, Park CHL, Almeida JP, Nakamura RE, Strabelli TMV, Pileggi B, Leme AC, Fominskiy E, Sakr Y, Lima M, Franco RA, Chan RPC, Piccioni MA, Mendes P, Menezes SR, Bruno T, Gaiotto FA, Lisboa LA, Dallan LAO, Hueb AC, Pomerantzeff PM, Filho RK, Jatene FB, Costa Auler Junior JO, Hajjar LA. Effect of perioperative goal-directed hemodynamic resuscitation therapy on outcomes following cardiac surgery: a randomized clinical. Trial and systematic review. Crit Care Med 2016; 44: 724-733.

18. Aya HD, Cecconi M, Hamilton M, Rhodes A. Goal-directed therapy in cardiac surgery: a systematic review and meta-analysis. Br J Anaesth 2013; 110: 510-517.

19. Heiberg J, El-Ansary D, Royse CF, Royse AG, Alsaddiquates AA, Canty DJ. Transthoracic and transoesophageal echocardiography: a systematic review of feasibility and impact on diagnosis, management and outcome after cardiac surgery. Anaesthesia 2016; 71: 1210-1221.

20. Kucewicz-Czech E, Krzych $Ł$, Ligowski M. Perioperative haemodynamic optimisation in patients undergoing non-cardiac surgery - a position statement from the Cardiac and Thoracic Anaesthesia Section of the Polish Society of Anaesthesiology and Intensive Therapy. Part 1. Anestesiol Intensive Ther 2017; 49: 6-15.

21. Kucewicz-Czech E, Krzych $Ł$, Ligowski M. Perioperative haemodynamic optimisation in patients undergoing non-cardiac surgery - a position statement from the Cardiac and Thoracic Anaesthesia Section of the Polish Society of Anaesthesiology and Intensive Therapy. Part 2. Anestesiol Intensive Ther 2017; 49: 16-27.

22. Minakata K, Sakata R. Perioperative control of blood glucose level in cardiac surgery. Gen Thorac Cardiovasc Surg 2013; 61: 61-66.

23. Vincent JL, Shehabi Y, Walsh TS, Pandharipande PP, Ball JA, Spronk P, Longrois D, Strřm T, Conti G, Funk GCh, Badenes R, Mantz J, Spies C, Takala J. Comfort and patient-centred care without excessive sedation: the eCASH concept. Intensive Care Med 2016; 42: 962-971.

24. Reade MC, Finfer S. Sedation and delirium in the intensive care unit. N Engl J Med 2014; 370: 444-454.

25. Gosselt AN, Slooter AJ, Boere PR, Zaal IJ. Risk factors for delirium after onpump cardiac surgery: a systematic review. Crit Care 2015; 19: 346.

26. Mariscalco G, Biancari F, Zanobini M, Cottini M, Piffaretti G, Saccocci M, Banach M, Beg C, Angelini GD. Bedside tool for predicting the risk of postoperative atrial fibrillation after cardiac surgery: the POAF Score. J Am Heart Assoc 2014; 3: e000752.

27. Krzych $七$ J, Kucewicz-Czech E. It is time for enhanced recovery after surgery in cardiac surgery. Kardiol Pol 2017; 75: 415-420.

28. Schaller SJ, Anstey M, Blobner M, Edrich T, Grabitz SD, Gradwohl-Matis I, Heim M, Houle T, Kurth T, Latronico N, Lee J, Meyer MJ, Peponis T, Talmor D, Velmahos GC, Waak K, Walz JM, Zafonte R, Eikermann M. Early, goal-directed mobilisation in the surgical intensive care unit: a randomised controlled trial. Lancet 2016; 388: 1377-1388. 